\title{
Studies in the genus Lotononis (Crotalarieae, Fabaceae). 1. Three new species of the section Aulacinthus from the Cape Province
}

\author{
B-E. VAN WYK*
}

Keywords: Cape Province, Lotononis section Aulacinthus, Fabaceae, new taxa

\section{ABSTRACT}

Three new species of the section Aulacinthus (E. Mey.) Benth. of Lotononis (DC.) Eckl. \& Zeyh. are described: $L$. comptonii B-E. van Wyk, $L$. dahlgrenii B-E. van Wyk and $L$. dissitinodis B-E. van Wyk. These species are related to $L$. gracilis (E. Mey.) Benth. and L. rigida (E. Mey.) Benth. and are all endemic to marginal fynbos areas of the south-western Cape. The section now comprises seven species.

\section{UITTREKSEL}

Drie nuwe soorte van die seksie Aulacinthus (E. Mey.) Benth. van Lotononis (DC.) Eckl. \& Zeyh. word beskryf: $L$. comptonii B-E. van Wyk. $L$. dahlgrenii B-E. van Wyk en $L$. dissitinodis B-E. van Wyk. Hierdie soorte is verwant aan $L$. gracilis (E. Mey.) Benth. en $L$. rigida (E. Mey.) Benth. en is almal endemies in marginale fynbosgebiede van die SuidwesKaap. Die seksie behels nou sewe soorte.

\section{INTRODUCTION}

The section Aulacinthus (E. Mey.) Benth. of Lotononis (DC.) Eckl. \& Zeyh. comprises a small group of poorly known fynbos shrubs. Species of this section are remarkably similar in their leaves and habit to some species of Lebeckia Thunb., Wiborgia Thunb. and Aspalathus L.

When Bentham (1843) changed the status of Aulacinthus E. Mey. to a section of Lotononis, he remarked on its similarity to other genera of the Crotalarieae but also noted its distinguishing floral and fruit characters. The upper calyx lobes are usually fused in pairs on either side and the fruit is relatively short, laterally inflated and has the lower suture sunken to various degrees. In terms of fruit characters, the verrucose upper suture is perhaps the most significant and useful diagnostic feature. The seeds of all the species are distinctly tuberculate and not smooth as in other genera of the Crotalarieae. Bentham (1843) and Harvey (1862) listed for section Aulacinthus, three species $[L$. gracilis (E. Mey.) Benth., L. rigida (E. Mey.) Benth. and $L$. viborgioides Benth.] to which Dümmer (1913) added one [L. leucoclada (Schltr.) Dümmer, transferred from Lebeckia].

As part of a continuing taxonomic study of the genus Lotononis, I investigated the section Aulacinthus and found three undescribed species that clearly belong to this group. These are described below.

The circumscription of Aulacinthus and its status as a section need to be reconsidered. As a group it gradually merges (through yet another group of undescribed species) with the section Polylobium (Eckl. \& Zeyh.) Benth. This problem, however, falls beyond the scope of the present paper.

* Department of Botany, Rand Afrikaans University, P.O. Box 524, Johannesburg 2000.

MS. received: 1987.08.17.
Lotononis comptonii $B-E$. van $W y k, s p$. nov. $L$. gracili (E. Mey.) Benth. valde affinis, sed habitu laxiore sparsiore, foliis ramunculisque sparse strigillosis (non dense albo-pubescentibus), stipulo unico in quoque nodo (in $L$. gracili stipulis omnino destitutis) et vexillo aurantiaco-rubro (in posteriore flavo) differt.

TYPE.-Cape, 3320 (Montagu): Laingsburg to Seweweekspoort Road, $9.5 \mathrm{~km}$ after entrance to Rietvlei Farm (-AD), 12.10.86, B-E. van Wyk 2l60 (PRE, holo.; BOL, C, JRAU, K, M, MO, NBG, SAAS. STE. iso.).

Lax, sparsely branched woody shrub, up to $0.4 \mathrm{~m}$ tall. Branches slightly corky, yellow-brown: young twigs sparsely strigillose. Leaves digitately trifoliolate (very rarely 4 or 5 -foliolate); petiole $(7-) 18-25(-42) \mathrm{mm}$ long, persistent for some time after the leaflets have been individually shed; leaflets obovate, narrowly oblong, or narrowly elliptical, (4-) $8-15(-21) \mathrm{mm}$ long. (1-) $2-3(-5) \mathrm{mm}$ wide, abaxially sparsely strigillose. adaxially glabrous. Stipules consistently present, single at each node, elliptic-oblong to narrowly lanceolate. (2-) 5-7 (-9) $\mathrm{mm}$ long. Inflorescences terminal. rarely subterminal, long-pedunculate, $60-150 \mathrm{~mm}$ long, sparsely (3-) 4-6 (-8) -flowered; bracts 2-3 (-5) mm long; bracteoles absent. Flowers 10-12 mm long. orange-red and yellow; pedicel 2-5 mm long. Calyx 6-8 $\mathrm{mm}$ long, with the lateral lobes on either side fused much higher up in pairs, minutely strigillose. Standard broadly ovate to orbicular, $8-12 \mathrm{~mm}$ long, longitudinally striate, orange to bright orange-red. Wing petals broadly oblong, slightly shorter than the keel: apex obtuse; sculpturing upper basal and upper central, in 4-5 rows of intercostal lunae. Keel petals broadly elliptical, auriculate and pocketed near the base. Anthers dimorphic. Pistil 10-12 mm long; ovary short, oblongovate, 4-6 mm long. Fruit 12-15 mm long, 4-5 mm wide, laterally much inflated. lower suture sunken. upper suture verrucose, glabrous. Seed suborbicular in side view, up to $2 \mathrm{~mm}$ long, distinctly tuberculate, reddish brown (Figure 1). 


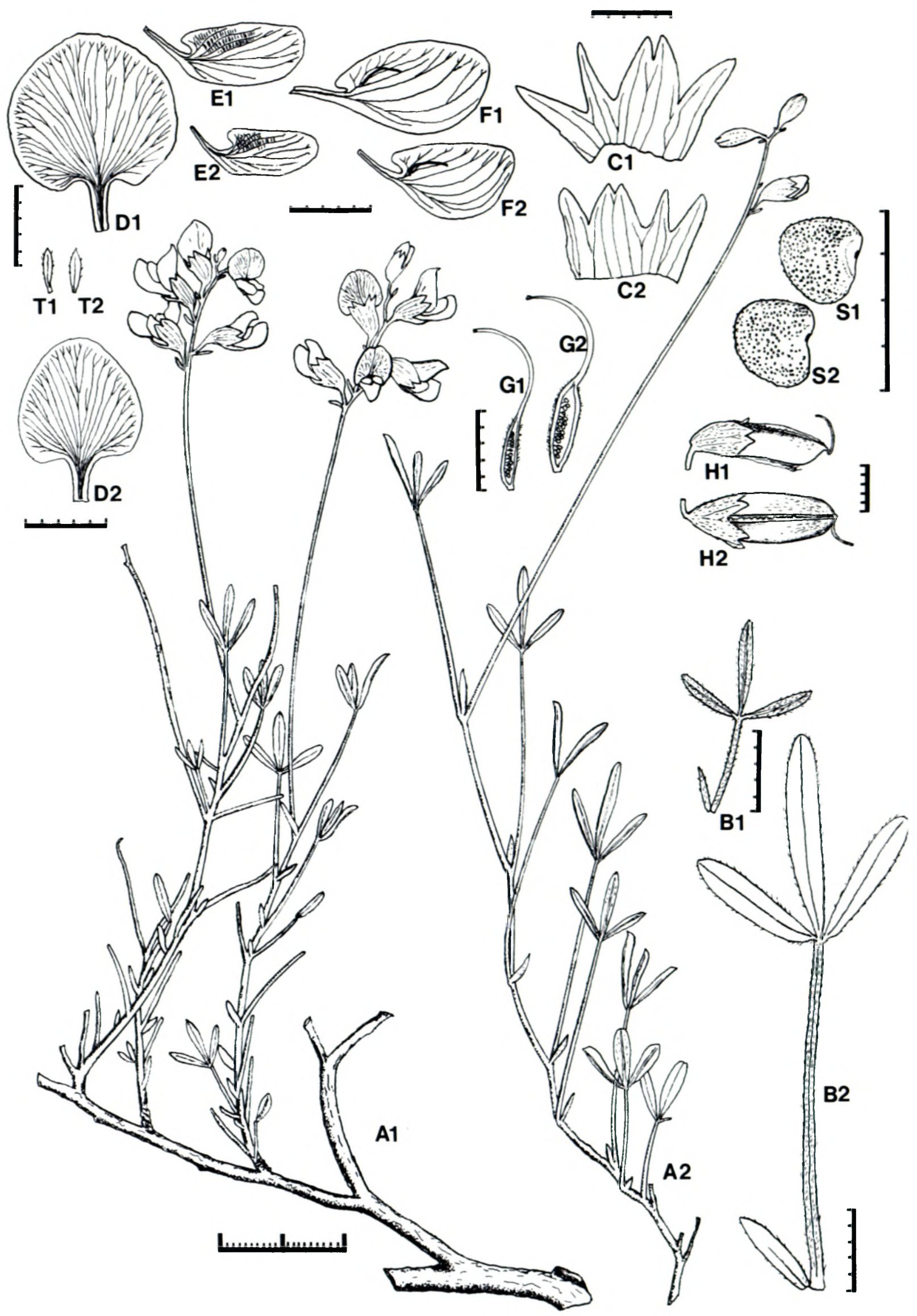

FIGURE 1.-Lotononis complonii. A1, A2, flowering branches; B1, B2, leaves, showing the single stipule and vestiture; $\mathrm{Cl}, \mathrm{C} 2, \mathrm{calyx}$ opened out. with the upper lobes to the right (C1) and to the left (C2), vestiture not shown: DI, D2, standard petals; E1, E2, wing petals: F1, F2, keel petals: G1, G2 pistils; H1, H2, fruit, in side and top view; S1, S2, seeds, showing the tuberculate surface; TI, T2, bracts. (Al, B2. Cl. C2. D2. E2. F2. GI \& T1 from $B V W$ 2160: A2 \& T2 from BVW' 2161; DI, E1, F1 \& G2 from $B V W 2185$; $\mathrm{B} 1, \mathrm{H} 1$ \& $\mathrm{H} 2$ from Compron 12166: S1 \& S2 from $B V W 2190$ ). Scale in $\mathrm{mm}$. 
This species is closely related to $L$. gracilis (E. Mey.) Benth., but differs in the more lax and sparse habit, the sparsely strigillose leaves and twigs (not densely whitepubescent), the presence of a single stipule to each node (stipules totally absent in $L$. gracilis) and in the orangered vexillum (yellow in $L$. gracilis).

$L$. comptonii is known only from two small populations on the northern slopes of the Witteberg and the Klein Swartberg (Figure 2), where it was found in dry fynbos vegetation on shallow, rocky soil. The specific epithet commemorates Prof. R. H. Compton (18861979), director of Kirstenbosch Botanical Garden for 34 years. He was responsible for the only collection known prior to my rediscovery of the species in 1986.

CAPE.-3320 (Montagu): Bantamskop, Witteberg (-BC), 27.10.1941, Compion 12166 (NBG. PRE); Bantamskop. $3 \mathrm{~km}$ from the top (-BC), 13.10.1986, B-E. van Wyk 2185 (JRAU, PRE. NBG), 2186 (BOL, JRAU, PRE, MO, NBG), 2187 (JRAU, PRE), 2/88, 2189 (JRAU), 2190 (JRAU, PRE). 3321 (Ladismith): Laingsburg to Seweweekspoort Road, 9.5 km from entrance of Rietvlei Farm (-AD), 12.10.1986, B-E. van Wyk 2160 (PRE, holo.: BOL, C, JRAU, K, M, MO, NBG, SAAS, STE, iso.), 2161 (BOL, JRAU. K. MO. NBG, STE), 2162 (BOL, GRA, JRAU, KMG, NH, PRE), 2163 (JRAU, PRE).

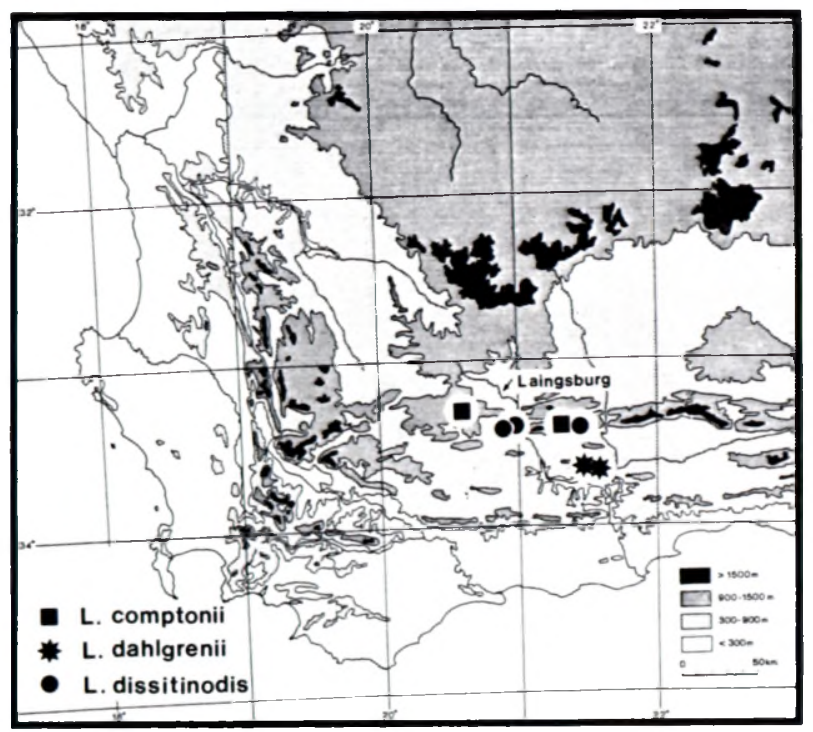

FIGURE 2.-The known geographical distribution of Lotononis comp-

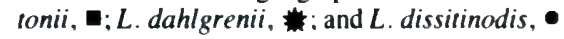

Lotononis dahlgrenii $B-E$. van $W y k, s p$. nov. $L$. rigidae (E. Mey.) Benth. similis, sed habitu etiam rigidiore lignosioreque, ramis lateralibus brevibus rigidis aliquantum spinescentibus, racemis longioribus latiore dispersis unifloratis ( 2 vel 3 -floratis in $L$. rigida), calyce sparse puberulo (in $L$. rigida dense patente pubescens), vexillo carinaque maioribus, ovario fructuque longioribus, differt. Etiam L. dissitinodi mei similis, sed foliolis valde brevioribus, minus conduplicatis, stipulis omnino destitutis, lobis calycis lateralibus connatis et vexillo valde minore differt.

TYPE.-Cape, 3321 (Ladismith): Ladismith Div., near top of Roodeberg Pass (-DA), 19.7.1954, Lewis 4709 (NBG, holo.).

Rigid woody shrub. Branches sparsely leafy; some of the lateral branches short, stiff and pungent; young twigs silky-sericeous. Leaves digitately trifoliolate, densely silky-sericeous; petiole very short, 1-3 mm long; leaflets small, narrowly oblanceolate to linear, $2-5(-8)$ mm long, slightly conduplicate. Stipules absent. Inflorescences subterminal on short lateral branches, 1flowered, rarely 2 -flowered; peduncle long, (6-) 10-15 $\mathrm{mm}$ in length; bracts small, oblong, up to $1 \mathrm{~mm}$ long: bracteoles absent. Flowers 12-13 mm long, yellow; pedicel 2-4 mm long. Calyx 6-8 mm long, lobes long, acuminate, with the lateral ones on either side fused much higher up in pairs, sparsely puberulous. Standard ovate and pointed, $10-12 \mathrm{~mm}$ long, with a line of hairs dorsally along the middle. Wing petals shorter than the keel, oblong; sculpturing upper basal and upper central. in 7-8 rows of intercostal lunae. Keel petals semicircular, obtuse, auriculate and pocketed near base. Anthers dimorphic. Pistil long; ovary linear, 7-12 mm long. Fruit linear, 12-15 mm long, inflated laterally; lower suture distinctly sunken, upper suture verrucose. Seed (immature) densely tuberculate (Figure 3).

This species is similar to L. rigida (E. Mey.) Benth. but differs in the habit which is even more rigid and woody, the short stiff and somewhat thorny lateral branches, the longer, more widely spaced and singleflowered racemes ( 2 or 3 -flowered in $L$. rigida), the sparsely puberulous calyx (densely and patently pubescent in $L$. rigida), the larger standard and keel and the longer ovary and fruit. It is also similar to $L$. dissitinodis B-E. van Wyk, but differs in the much shorter and less conduplicate leaflets, the total absence of stipules, the fused lateral calyx lobes and the much smaller standard.

$L$. dahlgrenii may easily be confused with species of Wiborgia and Aspalathus when not in flower. It appears to be a rare species and is only known from three specimens collected on the Rooiberg near Ladismith. The species is named after the late Prof. Rolf Dahlgren in recognition of his valuable contributions to the literature on Cape legumes.

CAPE.-3321 (Ladismith): Roodeberg summit (-CB), 24.3. 1940. Bond 263 (NBG): 3.1940. Lewis I211 (SAM): near top of Roodeberg Pass (-DA). 19.7.1954. Lewis 4709 (SAM)

Lotononis dissitinodis $B-E$. van $W y k, s p$. nov., strictim $L$. rigidae (E. Mey.) Benth. et $L$. dahlgrenii mei similis, sed internodiis valde longioribus, foliolis longioribus anguste linearibus conduplicatis, stipulis ad pedunculorum insertionem semper praesentibus, inflorescentibus foliis oppositis (non subterminalibus), calycis lobis subaequalibus, vexillo maximo, carina minore acutioreque, fructu minus turgido differt.

TYPE.-Cape, 3320 (Montagu): 14 miles [22.4 km] SSE of Laingsburg (-BD), 25.7.1959. Acocks 20502 (PRE, holo.; BOL. M, NBG, iso.).

Woody, sparsely branched shrub, up to $0.4 \mathrm{~m}$ tall Branches with very long internodes, young twigs densely sericeous. Leaves widely spaced on the twigs, digitately trifoliolate (very rarely 4 or 5 -foliolate), densely sericeous; petiole $(2-) 5-8(-10) \mathrm{mm}$ long, adaxially grooved; leaflets narrowly linear, (5-) 7-12 $(-15) \mathrm{mm}$ long, conduplicate, apices recurved at maturity. Stipules rarely present, at the insertion of the peduncles only, single or paired, linear, variable in length, 1-8 mm long. Inflorescences leaf-opposed, 1-flowered (rarely 2-flowered); peduncles variable in length, 5-20 $\mathrm{mm}$ long; bracts small, up to $1 \mathrm{~mm}$ long: bracteoles absent. Flowers large, 15-20mm long, yellow: pedicel 

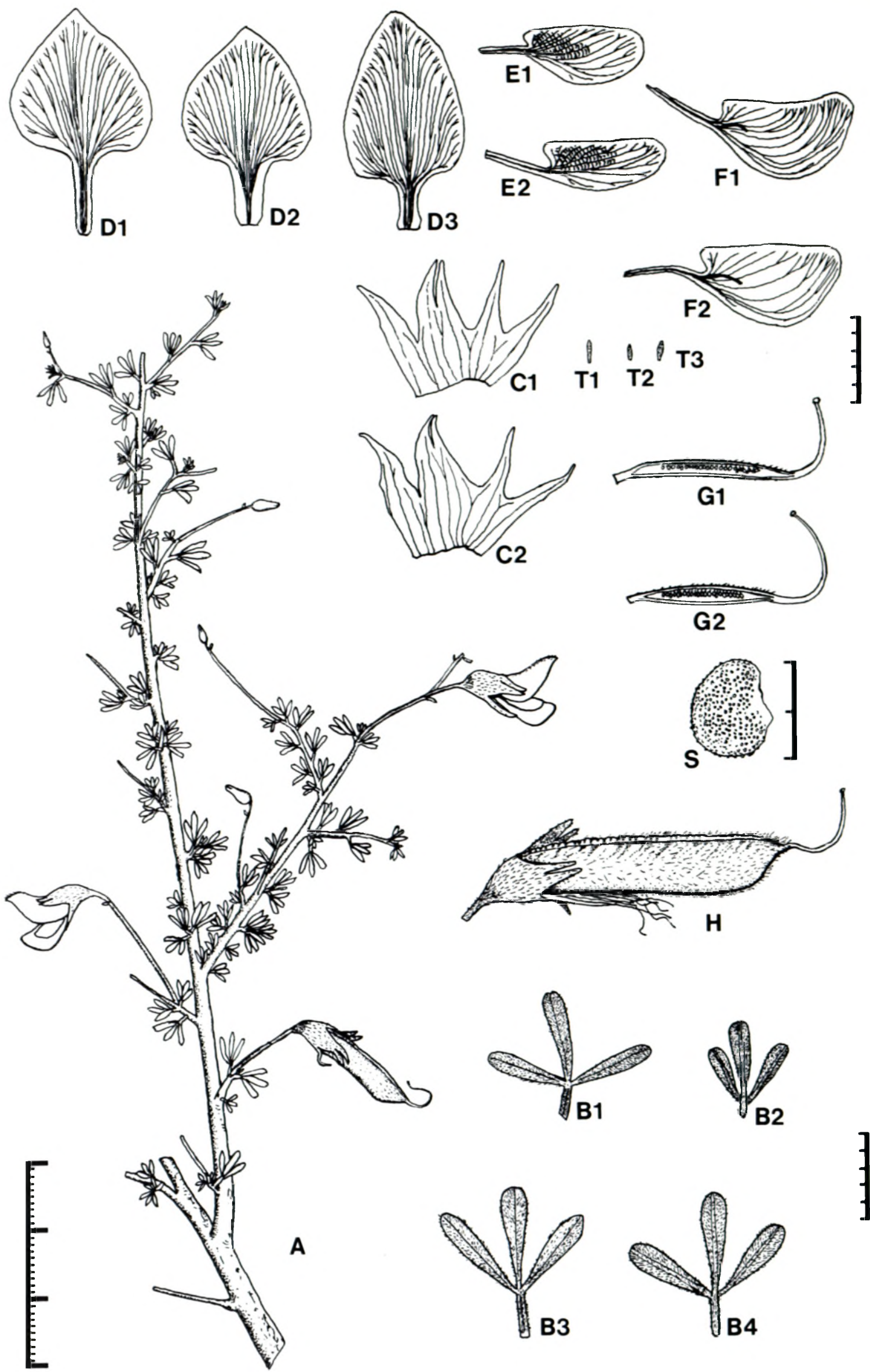

FIGURE 3.-Lotononis dahlgrenii. A, flowering branch; B1, B3, leaves in adaxial view; $\mathrm{B} 2$, B4, leaves in abaxial view; $\mathrm{Cl}, \mathrm{C} 2$, calyx opened out with upper lotes to the left, showing fusion of the lateral lobes: D1. D2, D3, standard petals, showing variation in shape: E1. E2, wing petals: FI. F2. keel petals: G1. G2. pistils: H. fruit: S. immature seed, showing tuberculate surface: T1, T2, T3, bracts. (A. B1. B2, C1. D1, E2. F2, G1 \& T3 from Lewis 4709; B3, B4, D2, F1, G2, H \& T2 from Bond 263: C2, D3, E1, S \& T1 from Lewis /2/1). Scale in $\mathrm{mm}$. 


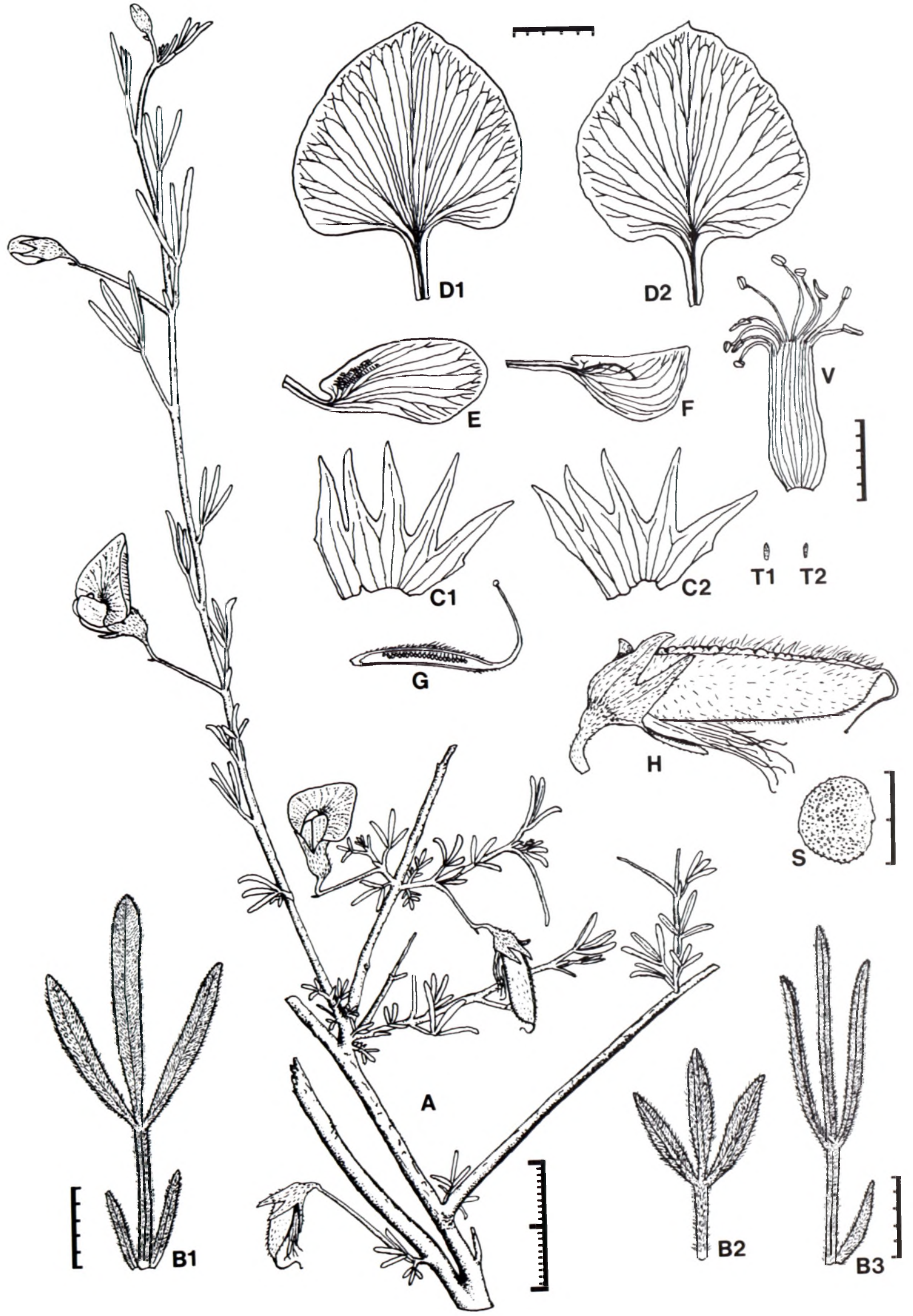

FIGURE 4.-Lotononis dissitinodis. A, flowering branch, showing the long internodes and leaf-opposed inflorescences; B1, B2, B3, leaves: BI, adaxial view, with leaflets opened out, showing paired stipules, B2, abaxial view, with leaflets opened out, stipules absent, B3, adaxial view, showing the normal conduplicate shape of the leaflets and a single stipule; CI, C2, calyx opened out. upper lobes to the left. showing the very slight fusion of the lateral lobes: D1, D2. standard petals (note the size): E. wing petal, showing the obovate shape; F, keel petal, showing the small size and pointed apex: V. androecium; G, pistil: $H$. fruit, showing verrucose upper suture: S, immature seed, showing tuberculate surface:T1. T2, bracts. (All from Acocks 20502 except D2, V \& T1 from Wurts 1520 and $\mathrm{T} 2$ from Levins 7414). Scale in $\mathrm{mm}$. 
1-3 mm long. Calyx 8-12 mm long; lobes long, subequal, minutely silky-puberulous. Standard large, broadly ovate, longer than the keel, 12-18 mm long, longitudinally striate. Wing petals obovate, longer than the keel; sculpturing upper basal, in \pm 4 rows of intercostal lunae and irregular transcostal lamellae. Keel petals short, semicircular, 8-10 mm long, acute. Anthers dimorphic. Pistil $9-10 \mathrm{~mm}$ long; ovary linear, 6-8 mm long. Fruit oblong-linear, 16-20 mm long, 5 $\mathrm{mm}$ wide, not much inflated; lower suture not or only slightly sunken; upper suture verrucose. Seed (immature) densely tuberculate (Figure 4).

Superficially the species is similar to $L$. rigida and $L$. dahlgrenii, but it differs in the much longer internodes, the longer, narrowly linear, conduplicate leaflets, the consistent presence of stipules at the insertion of the peduncles, the leaf-opposed (not subterminal) inflorescences, the subequally lobed calyx, the very large standard, the smaller, more acute keel petals and the less turgid fruit.

$L$. dissitinodis appears to be restricted to the Klein Swartberg (Figure 2) and is only known from four collections. The very long internodes are a diagnostic character useful in distinguishing it from other woody species, hence the specific epithet. Although it is closely related to other species of the section Aulacinthus, the very large standard, obovate wing petals and relatively small, pointed keel approaches the flower structure typical of the section Telina (E. Mey.) Benth. [L. prostrata (L.) Benth. and its allies]. This similarity is of interest since it may help to explain the origin of the Telina-type flower and inflorescence.

CAPE.-3320 (Montagu): Buffels Poon Berg, lower slopes (-BD), 5.7.1941, Levyns 7414 (BOL); Klein Swartberg. western end (-BD), 7.8.1957, Wurts 1520 (NBG, 2 sheets); 14 miles SSE of Laingsburg (-BD), 25.7.1959. Acocks 20502 (BOL, M. PRE); Seweweekspoort, $\mathrm{N}$ foothills of Klein Swartberg. Santo (-AD), 3.9.1982, Viviers \& Vlok 70 (STE).

\section{ACKNOWLEDGEMENTS}

I wish to thank Dr H. F. Glen (Botanical Research Institute, Pretoria) for the Latin translations and the Directors and staff of the cited herbaria for the loan of specimens. The taxonomic study of Lotononis is a registered Ph. D. project at the University of Cape Town.

\section{REFERENCES}

BENTHAM, G. 1843. Enumeration of Leguminosae, indigenous to southern Asia, and central and southern Africa. The London Journal of Botany 2: 504-613.

DÜMMER. R. A. 1913. A synopsis of the species of Lotononis, Eckl. \& Zeyh., and Pleiospora Harv. Transactions of the Royal Society of South Africa 3, 2: 275-335.

HARVEY, W. H. 1862. Leguminosae. In W. H. Harvey \& O. W. Sonder, Flora capensis 2: 47-66. Hodges \& Smith, Dublin. 